\title{
Central retinal artery occlusion - rethinking retinal survival time
}

\author{
Stephan Tobalem ${ }^{1}$, James S. Schutz ${ }^{1}$ and Argyrios Chronopoulos ${ }^{1,2^{*}}$
}

\begin{abstract}
Background: The critical time from onset of complete occlusion of the central retinal artery (CRA) to functionally significant inner retinal infarction represents a window of opportunity for treatment and also has medical-legal implications, particularly when central retinal artery occlusion (CRAO) complicates therapeutic interventions. Here, we review the evidence for time to infarction from complete CRAO and discuss the implications of our findings.

Methods: A Medline search was performed using each of the terms "central retinal artery occlusion", "retinal infarction", "retinal ischemia", and "cherry red spot" from 1970 to the present including articles in French and German. All retrieved references as well as their reference lists were screened for relevance. An Internet search using these terms was also performed to look for additional references.

Results: We find that the experimental evidence showing that inner retinal infarction occurs after 90-240 min of total CRAO, which is the interval generally accepted in the medical literature and practice guidelines, is flawed in important ways. Moreover, the retinal ganglion cells, supplied by the CRA, are part of the central nervous system which undergoes infarction after non-perfusion of 12-15 min or less.

Conclusions: Retinal infarction is most likely to occur after only 12-15 min of complete CRAO. This helps to explain why therapeutic maneuvers for CRAO are often ineffective. Nevertheless, many CRAOs are incomplete and may benefit from therapy after longer intervals. To try to avoid retinal infarcton from inadvertent ocular compression by a headrest during prone anesthesia, the eyes should be checked at intervals of less than 15'.
\end{abstract}

Keywords: Central retinal artery occlusion, Retinal infarction, Retinal stroke, Choroidal infarction, Post-operative visual loss, Cherry red spot

\section{Background}

Central retinal artery occlusion (CRAO) of sufficient duration causes a stroke, infarction of the inner retina including the retinal ganglion cells and their axons which form the optic nerve, central nervous system tissue $[1,2]$. The retinal ganglion cell layer is critically dependent on oxygen supplied by the end-artery circulation of the central retinal artery (CRA) [3, 4].

Retinal stroke from CRAO typically presents as acute, catastrophic, permanent visual loss in one eye, about $80 \%$ of the time with a visual acuity of $20 / 400$ or worse, an afferent pupillary defect, a classic retinal cherry red

\footnotetext{
*Correspondence: aris_c@web.de

'Department of Ophthalmology, University Hospitals and School of Medicine, Geneva, Switzerland

2Department of Ophthalmology, Addenbrooke's Hospital, Cambridge

University Hospital NHS Foundation Trust, Box 41, Hills Road, Cambridge CB2 OQQ, UK
}

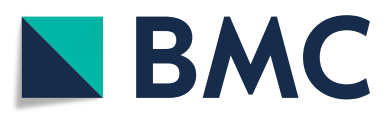

(c) The Author(s). 2018 Open Access This article is distributed under the terms of the Creative Commons Attribution 4.0 International License (http://creativecommons.org/licenses/by/4.0/), which permits unrestricted use, distribution, and

reproduction in any medium, provided you give appropriate credit to the original author(s) and the source, provide a link to the Creative Commons license, and indicate if changes were made. The Creative Commons Public Domain Dedication waiver (http://creativecommons.org/publicdomain/zero/1.0/) applies to the data made available in this article, unless otherwise stated. spot on ophthalmoscopy from opacification of the infarcted ganglion cell layer surrounding the fovea, and sometimes a visible CRA embolus or other retinal arterial emboli $[1,3,5]$. Sometimes, segmentation of retinal blood columns (box-carring) with stagnation of retinal arterial flow may be present, indicating complete CRAO $[1,3]$. Areas of inner retina supplied by cilioretinal arteries, which are common and not branches of the CRA, survive with visual function; if a cilioretinal artery supplies the macula despite surrounding infarction from CRAO, central vision may remain normal $[4,6]$. Infarction of the retinal ganglion cell somata is followed by progressive axonal degeneration with pale optic atrophy evident after some weeks [3]. The outer retina including the photoreceptors and underlying retinal pigment epithelium is supplied with oxygen by the lush choroidal circulation derived from the long and short posterior 
ciliary arteries and is not infarcted in pure CRAO [3]. Nevertheless, conduction of visual information centrally is blocked by the loss of retinal ganglion cell function.

The critical time from onset of complete CRA occlusion to inner retinal infarction represents a window of opportunity for emergency treatment to try to prevent catastrophic visual loss. We examined the experimental evidence for the interval between complete CRA occlusion and subsequent retinal ganglion cell infarction. Therapeutic implications for emergency treatment as well as medical-legal considerations are discussed.

\section{Methods}

Medline was systematically searched using the terms "retinal stroke", "central retinal artery occlusion", "retinal infarction", "retinal ischemia", and "cherry red spot" from 1970 to the present including articles in English, French, and German literature. These terms were connected with "or". An Internet search using these search terms was also performed to look for additional references with no year restriction. All retrieved references as well as their reference lists were screened for evidence relevant to determination of the time to infarction of complete CRAO as well as articles relevant to the physiology of retinal stroke.

\section{Eligible criteria}

All publications obtained from Internet-based searches were screened by the above predefined selection criteria. Eligible studies were all studies reporting on the time to retinal infarction from complete CRAO as well as articles relevant to the physiology of retinal stroke. Two reviewers (S.T. and S.J) completed the assessment of search results to identify included studies.

\section{Results}

It is generally accepted that the human ganglion cell layer will survive without infarction and with preservation of vision if CRA circulation is restored after up to 90 to $240 \mathrm{~min}$ of complete non-perfusion from CRAO [3, 7-15]. We find that this clinically important time limit for inner retinal non-perfusion has been greatly overestimated for several reasons.

First, it is based on a series of experiments on nonhuman primates by Hayreh and coworkers [11, 12, 14] which are inappropriate for extrapolation to human CRAO because:

a) The experiments were performed on barbiturate anesthetized monkeys. Barbiturate anesthesia has an important neuro-protective effect which prolongs neuronal survival during ischemia [16-20].

b) The experiments were not controlled for the presence of hypothermia in the experimental animals which was likely to have had an additional neuro-protective effect prolonging retinal ganglion cell survival [17].

c) Clamping of the CRA just before its entrance into the optic nerve sheath was performed in all the monkey experiments but is not an appropriate model for complete CRAO because there is collateral circulation to the CRA distal to the clamp in the monkey (and in the human eye) derived mostly from posterior ciliary artery branches of the ophthalmic artery [4, 21]. Persistent CRA perfusion was demonstrated in most of the experimental animals by fluorescein angiography with CRA filling in as little as $4 \mathrm{~s}$; this was caused by either incomplete clamping of the CRA or collateral circulation distal to the clamping $[11,12]$. Collateral circulation distal to the clamped CRA at its dural entry into the optic nerve sheath may very much delay or prevent inner retinal ischemia and infarction from CRAO; consequently, proper determination of the interval to inner retinal infarction after complete CRAO should be predicated on actual complete CRAO with no flow to the inner retina.

d) While it has been suggested that the site of CRA occlusion in humans is at the dural entry of the CRA into the optic nerve [13, 22-24], careful review of the references cited as evidence do not support this assertion nor can we find substantiation for this anywhere else in the peer reviewed literature. CRAO sometimes occurs at the posterior surface of the lamina cribrosa $[1,25]$. There is good clinical evidence that human CRA occlusion is often on the optic nerve head where the CRA narrows suddenly, branching into its major subdivisions, much more distal than the entrance of the CRA into the optic nerve dura [9]; the CRA at this point on the surface of the optic nerve head is normally an end-artery with no collateral circulation [4]. Complete CRAO with no flow through the CRA, whether embolic or thrombotic, is well documented and would not occur if occlusion were present at the entry of the CRA into the optic nerve dural sheath because there would be residual flow and filling of the CRA from variable fine arterial collaterals along the course of the CRA within the optic nerve and collaterals in the area of the scleral wall from the circle of Zinn-Haller [4, 26].

Second, the retinal ganglion cells are central nervous system tissue. The central nervous system undergoes progressive significant infarction after $12-15^{\prime}$ of nonperfusion [5, 27, 28]. Brain tissue is particularly vulnerable with neuronal death reported to begin after only $5 \mathrm{~min}$ of ischemia [29]. Patients undergoing temporary 
arterial occlusion during intracranial aneurysm surgery for more than $14 \mathrm{~min}$ are prone to secondary stroke [30] and a subsequent study found less than $10 \mathrm{~min}$ of occlusion generally safe [20]. New neurological deficit from temporary arterial clipping during aneurysm surgery was reported in $30.7 \%$ in cases with less than 8 min of clipping but $80.9 \%$ with clipping over 8 min [21]. Retinal tissue oxygen consumption per gram is even higher than brain which is one of the most energy consuming organs and it has been suggested the retina is equally or even more vulnerable to oxygen deprivation than brain [3137]. Cerebral oxygen consumption is about $3.5 \mathrm{ml} /$ $100 \mathrm{~g} / \mathrm{min}$ compared to about $3.8 \mathrm{ml} / 100 \mathrm{~g} / \mathrm{min}$ for inner cat retina and between 8 and $13 \mathrm{ml} / 100 \mathrm{~g} / \mathrm{min}$ for human retina, the highest in the body [38-41].

Third, oxygenation of the ganglion cells from the vitreous or choroid is clinically insufficient when breathing room air and cannot compensate for complete CRAO by prolonging inner retinal survival time [42, 43].

Consequently, it is most likely that complete CRAO in the human will cause progressive, significant, irreversible retinal ganglion cell death after 12-15 min.

\section{Discussion}

The time to inner retinal infarction from complete CRAO has clinical treatment implications for emergency treatment as well as medical-legal significance.

a) Time to emergency CRAO treatment - the window of opportunity

If complete CRAO is confirmed by observation of segmentation and stagnation of retinal arterial blood flow for longer than $15 \mathrm{~min}$ on successive fundus examinations, treatment is likely to be futile because of inner retinal infarction. However, it is not possible to be certain of the prior duration of a complete CRAO observed on a single fundus examination and a variable degree of reperfusion may occur at any time and intermittently. Even a cherry red spot is not a reliable sign of complete occlusion with retinal infarction because it may occur from inner retinal ischemia without infarction [44]. CRAO is most often incomplete or complete but temporary with subsequent intermittent or permanent degrees of reperfusion resulting from transient arterial spasm or break up of embolus or thrombus [24]. Residual circulation is present demonstrated on fluorescein angiography in most CRAO patients and even a modest level of perfusion may prolong inner retinal survival [45]. Consequently, patients presenting with CRAO usually are offered treatment even if the time from onset of occlusion is believed to be many hours when there is uncertainty regarding completeness and duration of the occlusion. Patients with incomplete occlusions are more likely to benefit from therapy [45] although, unfortunately, no strong evidence based treatment has been shown to be effective for CRAO [1, 3, 6, 9, 46].

Treatments for CRAO include:

- hyperbaric oxygen $[47,48]$.

- anticoagulation $[1,3]$.

- vasodilation by retrobulbar injection tolazoline or local anesthetic, sublingual isosorbide dinitrate, oral pentoxifylline, breathing elevated levels of carbon dioxide $[1,3,7,49,50]$.

- topical ocular hypotensive agents, intravenous mannitol and acetazolamide to decrease extramural arterial tissue pressure by lowering IOP [1, 3, 49].

- paracentesis with release of aqueous from the anterior chamber to lower IOP and restore perfusion or dislodge CRA embolus, an effective method of acute dramatic IOP lowering [1, 50-53].

- ocular massage to lower IOP or dislodge CRA embolus or thrombus $[1,3,6,49,54]$.

- fibrnolyitic therapy, intravenous or selective intraarterial thrombolysis most oftenwith tissue plasminogen activator (tPA), popular in some centers but with complications reported in up to $37 \%$ of cases [3, 5567]. Recently, a small uncontrolled series using tPA by intra-retinal arterial micro-cannulation has been reported with limited success [68].

CRAO treatments commonly offered at present are listed in Table 1; however, it is important to note that there is no generally accepted consensus with respect to CRAO treatment and treatment offered at different locations varies greatly according to local protocols and physician experience.

After ophthalmic examination and treatment of retinal stroke from CRAO, further urgent evaluation is indicated to search for a cause of occlusion or the source of a visible embolus because CRAO patients are at elevated risk for other cerebral or myocardial infarction $[1,3,6]$.

\section{b) Medical-legal implications}

Retinal survival time after complete CRAO may have important medical legal implications when a treating doctor is alleged not to have diagnosed or treated in a timely fashion, particularly when CRAO is iatrogenic, for example the result of acute retrobulbar hemorrhage following retrobulbar injection, blepharoplasty, orbital surgery, sinus surgery entering the orbit, and facial injections causing CRA embolization. In such cases, it is very important to recognize that there is no generally accepted, effective treatment for CRAO and also that inner retinal infarction occurs rapidly, within about $15 \mathrm{~min}$ if CRAO is complete. 
Table 1 Common Emergency CRAO Treatment Options

\begin{tabular}{ll}
\hline Treatment & Action \\
\hline $\begin{array}{l}\text { Sublingual isosorbide dinitrate } \\
\text { Carbontoxifylline }\end{array}$ & Vasodilation \\
& Vasodilation \\
Cerebral vasodilation \\
and increased oxygen \\
Retrobulbar alpha adenergic blocker & Vasodilation \\
(tolazoline) or local anesthetic & \\
Hyperbaric oxygen & Increased oxygen \\
Ocular massage & Attempt to dislodge \\
& emboli or thrombus \\
Systemic anticoagulation & Limit thrombosis \\
Intravenous acetazolamine & Reduce IOP to increase \\
and mannitol & perfusion pressure \\
Aqueous humor removal & Reduce IOP to increase \\
by paracentesis & perfusion pressure \\
Thrombolysis, intra-arterial & Dissolve thrombus \\
or systemic & \\
\hline
\end{tabular}

Combined CRAO and choroidal occlusion, sometimes iatrogenic, may be caused by acute, severe, intraocular pressure (IOP) elevation causing infarction of both inner and outer retina as well as optic nerve head with complete permanent loss of retinal function if occlusion is sufficiently prolonged. Such acute IOP elevation has two typical mechanisms:

1. Internal - severe IOP elevation can arise from acute internal ocular volume increase from intraocular injection or intraocular gas expansion following intraocular surgery resulting from too high gas concentration, nitrous oxide anesthesia, or reduced atmospheric pressure during flight or high altitude mountain ascent [69-71].

2. External - acute ocular pressure elevation can result from external pressure on the globe, for example by a head rest during prone general anesthesia, pre-operative ocular compression for intraocular surgery, acute retrobulbar hemorrhage, orbital infection with severe edema, acute large scleral buckle, orbital emphysema, as well as from a variety of objects pressing on the eye [72-82].

Retinal infarction in cases of combined CRAO and choroidal vascular occlusion from acute, highly elevated IOP will occur after only $12-15^{\prime}$ of complete CRAO. Consequently, the eyes of a prone patient positioned on a head rest during general anesthesia should be checked at intervals of $15 \mathrm{~min}$ or less.

\section{Conclusion}

Complete CRAO of more than 12-15 min duration is likely to be sufficient to cause stroke of the retinal ganglion cells which form the optic nerve. This may be one reason why no strong evidence based therapy exists for CRAO. If multiple serial fundus examinations show no retinal arterial flow as evidenced by segmentation and stagnation of the arterial blood columns for more than about $15^{\prime}$, treatment is likely to be futile. Otherwise, emergency treatment is offered after much longer intervals in most cases because it is usually not possible to be sure that CRAO has been complete from the onset of symptoms to the time of diagnosis. Retinal stroke from CRAO requires further urgent evaluation, after ophthalmic examination and treatment, to search for a cause of occlusion because CRAO patients are at elevated risk for other cerebral or myocardial infarction. To try to avoid CRAO from inadvertent ocular compression by a headrest during prone anesthesia, the eyes should be checked at intervals of less than $15^{\prime}$.

Abbreviations

CRA: Central retinal artery; CRAO: Central retinal artery occlusion; IOP: Intraocular pressure

Funding

The study was not funded.

Availability of data and materials

All data generated or analyzed during this study are included in this published article.

\section{Authors' contributions}

ST, JSS and AC have contributed equally in the conception, writing and editing of the manuscript. All authors have read and approved the manuscript.

Ethics approval and consent to participate

Not applicable.

Competing interests

The authors declare that they have no competing interests.

\section{Publisher's Note}

Springer Nature remains neutral with regard to jurisdictional claims in published maps and institutional affiliations.

Received: 15 December 2017 Accepted: 3 April 2018

Published online: 18 April 2018

References

1. Cugati S, Varma DD, Chen CS, Lee AW. Treatment options for central retinal artery occlusion. Curr Treat Options Neurol. 2013;1:63-77.

2. Monro TK. Optic nerve as part of the central nervous system. J Anat Physiol. 1895;Pt 1:45-8.

3. Varma DD, Cugati S, Lee AW, Chen CS. A review of central retinal artery occlusion: clinical presentation and management. Eye (London, England). 2013;6:688-97.

4. Michalinos A, Zogana S, Kotsiomitis E, Mazarakis A, Troupis T. Anatomy of the ophthalmic artery: a review concerning its modern surgical and clinical applications. Anat Res Int. 2015:591961. https://doi.org/10.1155/2015/591961.

5. Astrup J, Siesjö BK, Symon L. Thresholds in cerebral ischemia - the ischemic penumbra. Stroke. 1981;6:723-5.

6. Olsen TW, Pulido JS, Folk JC, Hyman L, Flaxel CJ, Adelman RA. Retinal and ophthalmic artery occlusions preferred practice pattern(R). Ophthalmology. 2017:2:P120-43.

7. Sharma S, Brown GC. In: Ryan SJ, editor. Retinal artery obstruction in: section 5, chapter 69, retina. Philadelphia: Mosby; 2006. 978-0-323-02598-0 978-0323-04091-4 978-0-323-04323-6. 
8. Hayreh SS, Zimmerman MB, Kimura A, Sanon A. Central retinal artery occlusion. Retinal survival time. Exp Eye Res. 2004;3:723-36.

9. McCannel CA. In: Basic and Clinical Science Course, editor. Retina and vitreous in basic and clinical science course; 2016. 133.978-1-61525-739-3.

10. Hayreh SS, Kolder HE, Weingeist TA. Central retinal artery occlusion and retinal tolerance time. Ophthalmology. 1980;1:75-8.

11. Hayreh SS, Weingeist TA. Experimental occlusion of the central artery of the retina. I. Ophthalmoscopic and fluorescein fundus angiographic studies. Br J Ophthalmol. 1980;12:896-912.

12. Hayreh SS, Weingeist TA. Experimental occlusion of the central artery of the retina. IV: retinal tolerance time to acute ischaemia. Br J Ophthalmol. 1980;11:818-25.

13. Hayreh SS. Prevalent misconceptions about acute retinal vascular occlusive disorders. Prog Retin Eye Res. 2005;4:493-519.

14. Hayreh SS, Jonas JB. Optic disk and retinal nerve fiber layer damage after transient central retinal artery occlusion: an experimental study in rhesus monkeys. Am J Ophthalmol. 2000;6:786-95.

15. Murphy-Lavoie H, Butler F and Hagan C. Central retinal artery occlusion treated with oxygen: a literature review and treatment algorithm. Undersea \& Hyperbaric Medicine: Journal of the Undersea and Hyperbaric Medical Society, Inc. 2012;39:943-53.

16. Kawaguchi M, Furuya H, Patel PM. Neuroprotective effects of anesthetic agents. J Anesth. 2005;2:150-6.

17. Steen PA, Michenfelder JD. Cerebral protection with barbiturates: relation to anesthetic effect. Stroke. 1978;2:140-2.

18. Steen PA, Michenfelder JD. Barbiturate protection in tolerant and nontolerant hypoxic mice: comparison with hypothermic protection. Anesthesiology. 1979;5:404-8.

19. Almaas R, Saugstad OD, Pleasure D, Rootwelt T. Effect of barbiturates on hydroxyl radicals, lipid peroxidation, and hypoxic cell death in human NT2N neurons. Anesthesiology. 2000;3:764-74.

20. Lavine SD, Masri LS, Levy ML, Giannotta SL. Temporary occlusion of the middle cerebral artery in intracranial aneurysm surgery: time limitation and advantage of brain protection. J Neurosurg. 1997;6:817-24.

21. Tanabe J, Ishikawa T, Moroi J, Suzuki A. Preliminary study on safe thresholds for temporary internal carotid artery occlusion in aneurysm surgery based on motor-evoked potential monitoring. Surg Neurol Int. 2014:5:47.

22. Hayreh SS. Pathogenesis of occlusion of the central retinal vessels. Am J Ophthalmol. 1971:5:998-1011.

23. Singh S, Dass R. The central artery of the retina. II. A study of its distribution and anastomoses. Br J Ophthalmol. 1960:44:280-99.

24. Singh S, Dass R. The central artery of the retina. I. Origin and course. Br J Ophthalmol. 1960;44:193-212.

25. Foroozan R, Savino PJ, Sergott RC. Embolic central retinal artery occlusion detected by orbital color Doppler imaging. Ophthalmology. 2002;4:744-7. discussion 747-748

26. Bron AJ, Tripathi RC, Tripathi BJ, Wolff E. Wolff's anatomy of the eye and orbit. London: Chapman \& Hall Medical; 1997. 978-0-412-41010-9

27. Raichle ME. The pathophysiology of brain ischemia. Ann Neurol. 1983;1:2-10.

28. Patterson JT, Hanbali F, Franklin RL, HWJ N. Ch 72 neurosurgery in Sabiston textbook of surgery, 18th edn. Philadelphia: Saunders Elsevier; 2008.

29. Lee JM, Grabb MC, Zipfel GJ, Choi DW. Brain tissue responses to ischemia. J Clin Invest. 2000;6:723-31.

30. Samson D, Batjer HH, Bowman G, Mootz L, Krippner WJ Jr, Meyer YJ, et al. A clinical study of the parameters and effects of temporary arterial occlusion in the management of intracranial aneurysms. Neurosurgery. 1994;1:22-8. discussion 28-29

31. Alder VA, Ben-Nun J, Cringle SJ. PO2 profiles and oxygen consumption in cat retina with an occluded retinal circulation. Invest Ophthalmol Vis Sci. 1990;6:1029-34.

32. Ames A 3rd. Earliest irreversible changes during ischemia. Am J Emerg Med. 1983;2:139-46

33. Ames A 3rd, Nesbett FB. Pathophysiology of ischemic cell death: I. Time of onset of irreversible damage; importance of the different components of the ischemic insult. Stroke. 1983:2:219-26.

34. Pournaras CJ, Riva CE, Tsacopoulos M, Strommer K. Diffusion of O2 in the retina of anesthetized miniature pigs in normoxia and hyperoxia. Exp Eye Res. 1989:3:347-60.

35. Pournaras CJ, Tsacopoulos M, Bovet J, Roth A. Diffusion of O2 in the normal and the ischemic retina of miniature pigs. Ophtalmologie. 1990;1:17-9.

36. Wangsa-Wirawan ND, Linsenmeier RA. Retinal oxygen: fundamental and clinical aspects. Arch Ophthalmol. 2003;4:547-57.
37. Yu DY, Cringle SJ. Oxygen distribution and consumption within the retina in vascularised and avascular retinas and in animal models of retinal disease. Prog Retin Eye Res. 2001;2:175-208.

38. Braun RD, Linsenmeier RA, Goldstick TK. Oxygen consumption in the inner and outer retina of the cat. Invest Ophthalmol Vis Sci. 1995;3:542-54.

39. Braun RD, Linsenmeier RA. Retinal oxygen tension and the electroretinogram during arterial occlusion in the cat. Invest Ophthalmol Vis Sci. 1995;3:523-41.

40. Hadanny A, Maliar A, Fishlev G, Bechor Y, Bergan J, Friedman M, Avni I, Efrati. Reversibility of retinal ischemia due to central retinal artery occlusion by hyperbaric oxygen. Clin Ophthalmol. 2017;11:115-25. https://doi.org/10. 2147/OPTH.S121307.

41. Gabrielli A, Layon AJ, Yu M. Civetta, Taylor and Kirby's critical care. New York: WW Norton; 2008

42. Yu DY, Cringle SJ. Oxygen distribution and consumption within the retina in vascularised and avascular retinas and in animal models of retinal disease. Prog Retin Eye Res. 2001;20:175-208.

43. Yu DY, Cringle SJ, Yu PK, Su EN. Intraretinal oxygen distribution and consumption during retinal artery occlusion and graded hyperoxic ventilation in the rat. Invest Ophthalmol Vis Sci. 2007;5:2290-6.

44. Terelak-Borys B, Skonieczna K, Grabska-Liberek I. Ocular ischemic syndrome a systematic review. Med Sci Monit. 2012;8:RA138-44.

45. McLeod D, Beatty S. Evidence for an enduring ischaemic penumbra following central retinal artery occlusion, with implications for fibrinolytic therapy. Prog Retin Eye Res. 2015;49:82-119.

46. Youn TS, Lavin P, Patrylo M, Schindler J, Kirshner H, Greer DM, Schrag M. Current treatment of central retinal artery occlusion: a national survey. J Neurol. 2018;265(2):330-35. https://doi.org/10.1007/s00415-017-8702-x.

47. Beatty $\mathrm{S}, \mathrm{Au}$ Eong KG. Acute occlusion of the retinal arteries: current concepts and recent advances in diagnosis and management. J Accid Emerg Med. 2000;5:324-9.

48. Deutsch TA, Read JS, Ernest JT, Goldstick TK. Effects of oxygen and carbon dioxide on the retinal vasculature in humans. Arch Ophthalmol. 1983;8:1278-80.

49. Rumelt S, Dorenboim Y, Rehany U. Aggressive systematic treatment for central retinal artery occlusion. Am J Ophthalmol. 1999;6:733-8.

50. Atebara NH, Brown GC, Cater J. Efficacy of anterior chamber paracentesis and Carbogen in treating acute nonarteritic central retinal artery occlusion. Ophthalmology. 1995:12:2029-34. discussion 2034-2025

51. Hwang CK, Kolomeyer AM, Brucker AJ. Optical coherence tomography angiography of a central retinal artery occlusion before and after anterior chamber paracentesis. Ophthalmology. 2017;5:608.

52. Fiess A, Cal O, Kehrein S, Halstenberg S, Frisch I, Steinhorst UH. Anterior chamber paracentesis after central retinal artery occlusion: a tenable therapy? BMC Ophthalmol. 2014;14:28.

53. Trivedi D, Denniston AK, Murray PI. Safety profile of anterior chamber paracentesis performed at the slit lamp. Clin Exp Ophthalmol. 2011;8:725-8.

54. Ffytche TJ. A rationalization of treatment of central retinal artery occlusion. Trans Ophthalmol Soc U K. 1974;2:468-79.

55. Schrag M, Youn T, Schindler J, Kirshner H, Greer D. Intravenous fibrinolytic therapy in central retinal artery occlusion: a patient-level meta-analysis. JAMA Neurol. 2015;72(10):1148-54. https://doi.org/10.1001/jamaneurol.2015.1578.

56. Hazin R, Dixon JA, Bhatti MT. Thrombolytic therapy in central retinal artery occlusion: cutting edge therapy, standard of care therapy, or impractical therapy? Curr Opin Ophthalmol. 2009;3:210-8.

57. Mehta N, Marco RD, Goldhardt R, Modi Y. Central retinal artery occlusion: acute management and treatment. Curr Ophthalmol Rep. 2017:5(2):149-59. https://doi.org/10.1007/s40135-017-0135-2.

58. Agarwal N, Gala NB, Baumrind B, Hansberry DR, Thabet AM, Gandhi CD, Prestigiacomo CJ. Endovascular management of central retinal arterial occlusion. Vasc Endovasc Surg. 2016;50(8):579-81. https://doi.org/10.1177/ 1538574416682158.

59. Schumacher M, Schmidt D, Jurklies B, Gall C, Wanke I, Schmoor C, Maier-Lenz H Solymosi L, Brueckmann H, Neubauer AS, Wolf A, Feltgen N, EAGLE-Study Group. Central retinal artery occlusion: local intra-arterial fibrinolysis versus conservative treatment, a multicenter randomized trial. Ophthalmology. 2010; 117(7):1367-75.e1. https://doi.org/10.1016/j.ophtha.2010.03.061.

60. Schumacher M, Schmidt D, Wakhloo AK. Intra-arterial fibrinolytic therapy in central retinal artery occlusion. Neuroradiology. 1993;8:600-5.

61. Gilbert AL, Choi C, Lessell S. Acute Management of Central Retinal Artery Occlusion. Int Ophthalmol Clin. 2015;55(4):157-66. https://doi.org/10.1097/ ॥0.0000000000000087. 
62. Arnold M, Koerner U, Remonda L, Nedeltchev K, Mattle HP, Schroth G, et al. Comparison of intra-arterial thrombolysis with conventional treatment in patients with acute central retinal artery occlusion. J Neurol Neurosurg Psychiatry. 2005;2:196-9.

63. Aldrich EM, Lee AW, Chen CS, Gottesman RF, Bahouth MN, Gailloud P, et al. Local intraarterial fibrinolysis administered in aliquots for the treatment of central retinal artery occlusion: the Johns Hopkins Hospital experience. Stroke. 2008;6:1746-50.

64. Richard G, Lerche RC, Knospe V, Zeumer H. Treatment of retinal arterial occlusion with local fibrinolysis using recombinant tissue plasminogen activator. Ophthalmology. 1999;4:768-73.

65. Weber J, Remonda L, Mattle HP, Koerner U, Baumgartner RW, Sturzenegger $M$, et al. Selective intra-arterial fibrinolysis of acute central retinal artery occlusion. Stroke. 1998;10:2076-9.

66. Padolecchia R, Puglioli M, Ragone MC, Romani A, Collavoli PL. Superselective intraarterial fibrinolysis in central retinal artery occlusion. AJNR Am J Neuroradiol. 1999:4:565-7.

67. Hattenbach LO, Kuhli-Hattenbach C, Scharrer I, Baatz H. Intravenous thrombolysis with low-dose recombinant tissue plasminogen activator in central retinal artery occlusion. Am J Ophthalmol. 2008;5:700-6.

68. Kadonosono K, Yamane S, Inoue M, Yamakawa T, Uchio E. Intra-retinal arterial cannulation using a microneedle for central retinal artery occlusion. Sci Rep. 2018;1:1360.

69. Fang IM, Huang JS. Central retinal artery occlusion caused by expansion of intraocular gas at high altitude. Am J Ophthalmol. 2002;4:603-5.

70. Baath J, Ells AL, Crichton A, Kherani A, Williams RG. Safety profile of intravitreal triamcinolone acetonide. Journal of ocular pharmacology and therapeutics: the official journal of the Association for Ocular. Pharmacol Ther. 2007;3:304-10

71. Fu AD, McDonald HR, Eliott D, Fuller DG, Halperin LS, Ramsay RC, et al. Complications of general anesthesia using nitrous oxide in eyes with preexisting gas bubbles. Retina. 2002;5:569-74.

72. Morgan CM, Schatz H, Vine AK, Cantrill HL, Davidorf FH, Gitter KA, et al. Ocular complications associated with retrobulbar injections. Ophthalmology. 1988:5:660-5.

73. Epstein NE. Perioperative visual loss following prone spinal surgery: a review. Surg Neurol Int. 2016;Suppl 13:S347-60.

74. Leibovitch I, Casson R, Laforest C, Selva D. Ischemic orbital compartment syndrome as a complication of spinal surgery in the prone position. Ophthalmology. 2006;1:105-8.

75. Brown GC, Magargal LE, Sergott R. Acute obstruction of the retinal and choroidal circulations. Ophthalmology. 1986;11:1373-82.

76. Walkup HE, Murphy JD. Retinal ischemia with unilateral blindness-a complication occurring during pulmonary resection in the prone position; report of two cases. J Thorac Surg. 1952;2:174-5.

77. Hoski JJ, Eismont FJ, Green BA. Blindness as a complication of intraoperative positioning. A case report. J Bone Joint Surg Am. 1993;8:1231-2.

78. Grossman W, Ward WT. Central retinal artery occlusion after scoliosis surgery with a horseshoe headrest. Case report and literature review. Spine. 1993;9:1226-8.

79. Wolfe SW, Lospinuso MF, Burke SW. Unilateral blindness as a complication of patient positioning for spinal surgery. A case report. Spine. 1992;5:600-5.

80. Jampol LM, Goldbaum M, Rosenberg M, Bahr R. Ischemia of ciliary arterial circulation from ocular compression. Arch Ophthalmol. 1975;12:1311-7.

81. Newman NJ. Perioperative visual loss after nonocular surgeries. Am J Ophthalmol. 2008:4:604-10.

82. American Society of Anesthesiologists Task Force on Perioperative Visual L. Practice advisory for perioperative visual loss associated with spine surgery: an updated report by the American Society of Anesthesiologists Task Force on perioperative visual loss. Anesthesiology. 2012;2:274-85.

Ready to submit your research? Choose BMC and benefit from:

- fast, convenient online submission

- thorough peer review by experienced researchers in your field

- rapid publication on acceptance

- support for research data, including large and complex data types

- gold Open Access which fosters wider collaboration and increased citations

- maximum visibility for your research: over $100 \mathrm{M}$ website views per year

At BMC, research is always in progress.

Learn more biomedcentral.com/submissions 